\title{
PENGGUNAAN DAUN SAMBILOTO UNTUK PHARYNGITIS
}

\author{
Susilo Yulianto \\ Kementerian Kesehatan Politeknik Kesehatan Surakarta Jurusan Jamu
}

\begin{abstract}
The Knowledge Society, Tamarind, Cough. Cough is one of the body's defense mechanisms, especially respiratory should be managed properly. Cough mechanism depends on five components: cough receptors, afferent nerve center, cough, nerve efferent, and effector. Based on preliminary studies conducted by the authors obtained the data that the knowledge society is very diverse Bakung village. The purpose of this study to determine the knowledge society Bakung village, Jogonalan, Klaten of tamarind to cough. This research is descriptive quantitative research with cross sectional approach. The sampling technique using a quota sampling with 30 respondents. Data collection instruments used were questionnaires knowledge of tamarind. Data was analyzed by descriptive analysis. Results of analysis of the data showed that respondents who have a good knowledge of a number of 27 respondents (90\%), while respondents who have sufficient knowledge of three respondents (10\%). The conclusion of this study that people's knowledge of tamarind to cough, with both categories (90\%), and knowledge of the category enough (10\%).
\end{abstract}

Keywords: Knowledge Society, Tamarind, Cough.

Abstrak: Penggunaan Daun Sambiloto, Pharyngitis. Pharyngitis adalah suatu penyakit peradangan yang menyerang tenggorok atau hulu kerongkongan (pharynx). Kadang juga disebut sebagai radang tenggorok. Radang ini bisa disebabkan oleh virus atau bakteri, disebabkan daya tahan yang lemah.Berdasarkan studi pendahuluan yang dilakukan oleh peneliti didapatkan data tentang penggunaan daun sambiloto untuk pharyngitis sangat beragam. Tujuan penelitian ini untuk mengetahui penggunaan daun sambiloto untuk pharyngitis.Penelitian ini merupakan penelitian deskriptif kuantitatif dengan pendekatan cross sectional. Teknik pengambilan sampel menggunakan quota sampling dengan 30 responden. Instrumen pengumpulan data yang digunakan yaitu angket pengetahuan tentang asam jawa. Analisa data dilakukan dengan analisa deskriptif. Hasil analisa data menunjukkan bahwa responden yang memiliki pengetahuan baik sejumlah 27 responden (90\%), sedangkan responden yang memiliki pengetahuan cukup 3 responden (10\%). Kesimpulan penelitian ini bahwa pengetahuan masyarakat tentang asam jawa untuk batuk, dengan kategori baik (90\%), dan pengetahuan dengan kategori cukup (10\%).

Kata Kunci:pengetahuan masyarakat, asam jawa, batuk.

\section{PENDAHULUAN}

Pharyngitis atau penyakit radang tenggorokan merupakan sebuah keadaan dimana terdapat bengkak atau penebalan pada dinding tenggorokan. Bengkak pada tenggorokan tersebut berwarna merah dan terdapat bintik-bintik putih. Biasanya penderita radang akan merasakan sakit 
saat menelan makanan. Ada beberapa hal yang bisa memicu adanya radang pada tenggorokan. Ada baiknya untuk mengetahui beberapa penyebabnya agar kita lebih bisa menjaga kesehatan agar terhindar dari penyakit tersebut.

Penyebab utama pharyngitis ialah virus. Hampir $80 \%$ terjadinya penyakit tersebut disebabkan oleh virus. Dari virus tersebut, biasanya penderita akan merasa demam, kemudian batuk dan pilek. Terjadinya batuk dan pilek yang terusmenerus dapat menyebabkan adanya iritasi pada tenggorokan dan hal ini lah yang memicu terjadinya radang. Virus yang menyebabkan penyakit ini adalah virus coxsackie, yaitu virus yang biasa menyerang tangan, kaki dan mulut. Selain virus, radang juga bisa disebabkan oleh alergi yang berakibat pada iritasi di tenggorokan. Bakteri yang bernama streptokokus terdapat pada tenggorokan merupakan salah satu penyebab yang lain, bakteri ini menyebabkan pembengkakan sehingga saat menelan biasanya ada rasa sakit yang luar biasa. Radang yang disebabkan oleh bakteri biasanya gejalanya lebih parah. Seringkali pembengkakan diikuti dengan nanah dan muntah dan hal ini pun akan berakibat pada pembengkakan kelenjar amandel. Akan tetapi, bakteri merupakan penyebab yang jarang ditemui pada radang tenggorokan karena kebanyakan penyakit ini disebabkan oleh virus.

Pharyngitis merupakan salah satu gejala utama yang membawa pasien pada sarana kesehatan selain demam, diare, dan sesak. Pharyngitis merupakan karunia Tuhan yang berguna sebagai pertahanan tubuh khususnya pertahanan respiratorik. Klasifikasi batuk bermacam-macam tetapi umumnya dibagi dalam kelompok besar yaitu Pharyngitis akut dan Pharyngitis kronik. Untuk menentukan etiologi Pharyngitis kronik faktor usia merupakan petunjuk yang cukup penting.

Daun sambiloto merupakan suatu tumbuhan tropis dan termasuk tumbuhan berbuah polong. Daging asam jawa sangat populer, dan digunakan dalam aneka bahan masakan atau bumbu diberbagai belahan dunia.

Pengetahuan adalah hasil penginderaan manusia, atau hasil tahu seseorang terhadap objek melalui indera yang dimilikinya (mata, hidung, telinga dan sebagainya). Sebagian besar pengetahuan seseorang diperoleh melalui indera pendengaran dan indera penglihatan (Notoatmodjo, 2010). Pengetahuan itu sendiri dipengaruhi oleh faktor pendidikan formal. Namun bukan berarti orang yang berpendidikan rendah memiliki pengetahuan yang rendah.

Bangsa Indonesia telah lama mengenal dan menggunakan tanaman berkhasiat obat sebagai salah satu upaya dalam menanggulangi masalah kesehatan. Pengetahuan tentang tanaman berkhasiat obat berdasar pada pengalaman dan keterampilan yang secara turun temurun telah diwariskan dari satu generasi ke generasi berikutnya.

Berdasarkan hasil studi pendahuluan yang telah dilakukan oleh peneliti mengenai pengetahuan masyarakat tentang penggunaan daun sambiloto untuk pharyngitis, melalui wawancara dengan 7 responden yaitu Masyarakat di Desa Bakung, Jogonalan, Klaten, hanya 3 orang (43\%) yang mengerti pharyngitis dan 2 orang $(28 \%)$ yang mengerti penggunaan daun sambiloto untuk pharyngitis di Bakung, Jogonalan, Klaten. 


\section{METODE PENELITIAN}

Jenis penelitian ini deskriptif kuantitatif menggunakan rancangan cross sectional. Menggunakan variabel tunggal yaitu pengetahuan masyarakat tentang penggunaan daun sambiloto untuk pharyngitis. Sampel berjumlah 30 orang. Teknik sampling menggunakan quota sampling.Instrumen penelitian menggunakan angket.

Sebelum angket digunakan dalam penelitian, angketdiujicobakan terlebih dahulu untuk mengetahui validitas dan reliabilitas angket tersebut. Uji validitas dan reliabilitas dilaksanakan pada 30 responden yang memiliki ciri-ciri yang sama dengan responden di tempat penelitian dilaksanakan. Validitas dianalisis dengan rumus korelasi Pearson product moment, sedangkan reliabilitas dianalisis dengan rumus Alpha Cronbach. Validitas dan reliabilitas dilakukan dengan menggunakan Stastistical Product and Service Solution(SPSS) versi 16.0. Pengolahan datanya yaitu editting, processing, cleaning. Analisa datanya analisa univariat atau deskriptif.

\section{HASIL PENELITIAN}

\section{Distribusi Frekuensi Umur}

Dari 30 responden yang diteliti, didapatkan responden yang berusia 19-28 tahun sebanyak 11 orang dengan persentase $36,67 \%$, responden usia $29-38$ tahun sebanyak 7 orang dengan persentase $23,33 \%$, responden usia $39-48$ tahun sebanyak 8 orang dengan persentase $26,67 \%$ dan responden usia 49-58 tahun sebanyak 4 orang dengan persentase $13,33 \%$.
Tabel 1.

Distribusi Frekuensi Umur

\begin{tabular}{lll}
\hline Usia & Frekuensi & \% \\
\hline $19-28$ & 11 & 36,67 \\
$29-38$ & 7 & 23,33 \\
$39-48$ & 8 & 26,67 \\
$49-58$ & 4 & 13,33 \\
\hline Jumlah & 30 & 100 \\
\hline
\end{tabular}

\section{Distribusi Frekuensi Jenis kelamin}

Dari 30 responden yang diteliti, terdapat responden yang berjenis kelamin laki-laki 12 orang, dengan persentase 40 persen dan responden berjenis kelamin perempuan sebanyak 18 orang dengan persentase $60 \%$.

Tabel 2.

Distribusi Frekuensi Jenis kelamin

\begin{tabular}{lcc} 
Jenis & Frekuensi & $(\boldsymbol{\%})$ \\
Kelamin & & \\
\hline Laki-laki & 12 & 40 \\
Perempuan & 18 & 60 \\
Jumlah & 30 & 100
\end{tabular}

\section{Distribusi Frekuensi Tingkat \\ Pendidikan}

Dari 30 responden yang diteliti, tingkat pendidikan responden SD 3 orang dengan persentase $10,01 \%$, tingkat pendidikan responden SMP 7 orang dengan persentase $23,33 \%$ dan tingkat pendidikan responden SMA 20 orang dengan persentase $66,66 \%$.

Tabel 3

Distribusi Frekuensi Tingkat Pendidikan

\begin{tabular}{lcc}
\hline Pendidikan & Frekuensi & $(\%)$ \\
\hline SD & 3 & 10,01 \\
SMP & 7 & 23,33 \\
SMA & 20 & 66,66 \\
Jumlah & 30 & 100 \\
\hline
\end{tabular}




\section{Distribusi Pengetahuan Masyarakat}

Dari 30 responden yang diteliti, pengetahuan masyarakat tentang penggunaan daun sambiloto untuk pharyngitis 27 orang baik dengan persentase $90 \%$ dan pengetahuan cukup 3 responden dengan persentase $10 \%$.

\section{Tabel 4}

Distribusi Pengetahuan Masyarakat

\begin{tabular}{lcc}
\hline Kriteria & Frekuensi & \% \\
\hline Baik & 27 & 90 \\
Cukup & 3 & 10 \\
Jumlah & 30 & 100 \\
\hline
\end{tabular}

Hasil nilai pengetahuan masyarakat tentang penggunaan daun sambiloto untuk pharyngitis, yang mendapat nilai lebih dari 75 sebanyak 27 orang dan yang mendapat nilai kurang dari 75 sebanyak 3 orang.

Tabel 5

\begin{tabular}{rlc}
\multicolumn{2}{c}{ Hasil Nilai Pengetahuan Masyarakat } \\
\hline NO. & $\begin{array}{c}\text { IDENTITAS } \\
\text { REPONDEN }\end{array}$ & $\begin{array}{c}\text { NILAI } \\
\text { RESPONDEN }\end{array}$ \\
\hline 1 & Responden 1 & 82,14 \\
2 & Responden 2 & 75,00 \\
3 & Responden 3 & 82,14 \\
4 & Responden 4 & 96,42 \\
5 & Responden 5 & 92,85 \\
6 & Responden 6 & 96,42 \\
7 & Responden 7 & 100,0 \\
8 & Responden 8 & 96,42 \\
9 & Responden 9 & 96,42 \\
10 & Responden 10 & 92,85 \\
11 & Responden 11 & 92,85 \\
12 & Responden 12 & 85,71 \\
13 & Responden 13 & 82,14 \\
14 & Responden 14 & 78,57 \\
15 & Responden 15 & 75,00 \\
16 & Responden 16 & 82,14 \\
17 & Responden 17 & 89,28 \\
18 & Responden 18 & 100,0 \\
19 & Responden 19 & 82,14 \\
20 & Responden 20 & 96,42 \\
21 & Responden 21 & 82,14 \\
22 & Responden 22 & 67,85 \\
\hline
\end{tabular}

\begin{tabular}{llc}
23 & Responden 23 & 89,28 \\
24 & Responden 24 & 67,85 \\
25 & Responden 25 & 96,42 \\
26 & Responden 26 & 85,71 \\
27 & Responden 27 & 100,0 \\
28 & Responden 28 & 75,00 \\
29 & Responden 29 & 64,28 \\
30 & Responden 30 & 100,0 \\
\hline \multicolumn{3}{c}{ Distribusi frekuensi pengetahuan } \\
masyarakat, yang mendapat prosentase \\
paling tinggi pada nilai kategori \\
pernyataan untuk pharyngitis 92,85 dan \\
100 sebanyak 12 responden, sedangkan \\
yang paling tinggi pada nilai kategori \\
pernyataan tentang daun sambiloto 92,85 \\
sebanyak 9 responden (30\%).
\end{tabular}

Tabel 6.

\section{Hasil Pengetahuan Masyarakat}

\begin{tabular}{llll}
\hline $\begin{array}{l}\text { Kategori } \\
\text { Pertanyaan }\end{array}$ & Nilai & f & \% \\
\hline Untuk Batuk & 50,00 & 3 & 10,0 \\
& 57,14 & 3 & 10,0 \\
& 64,28 & 2 & 6,66 \\
& 71,42 & 3 & 10,0 \\
& 78,57 & 5 & 16,67 \\
& 85,71 & 2 & 6,66 \\
& 92,85 & 6 & 20,0 \\
& 100,0 & 6 & 20,0 \\
\hline Total & & $\mathbf{3 0}$ & $\mathbf{1 0 0}$ \\
\hline & & & \\
\hline Kategori & \multirow{2}{*}{ Nilai } & $\mathbf{F}$ & $\mathbf{\%}$ \\
Pertanyaan & & & \\
\hline Asam Jawa & 64,28 & 1 & 3,33 \\
& 71,42 & 6 & 20,0 \\
& 78,57 & 5 & 16,67 \\
& 85,71 & 7 & 23,33 \\
& 92,85 & 9 & 30,0 \\
& 100,0 & 2 & 6,45 \\
\hline Total & & & \\
\hline & & $\mathbf{3 0}$ & $\mathbf{1 0 0}$ \\
\hline
\end{tabular}

\section{PEMBAHASAN}

Berdasarkan hasil penelitian Pengetahuan Masyarakat Tentang penggunaan daun sambiloto untuk pharyngitis Di Bakung, Jogonalan, Klaten, pembahasannya sebagai berikut: 
Hal ini menunjukkan bahwa umur mempengaruhi terhadap daya tangkap dan pola pikir seseorang. Semakin bertambah usia akan semakin berkembang pula daya tangkap dan pola pikirnya, sehingga pengetahuan yang diperolehnya akan semakin membaik (Budiman danRiyanto, 2013). Sebagian besar tergolong pada kategori baik yaitu terdapat pada kelompok usia>20 tahun. Hal ini disebabkan proses perkembangan mental bertambah matang, terutama ketika berusia dewasa. Pada aspek psikologis atau mental taraf berpikir seseorang semakin matang dan dewasa. Sehingga dapat disimpulkan bahwa usia seseorang berpengaruh dalam penerimaan sumber informasi. Semakin tinggi umur seseorang, diharapkan semakin baik pula pengetahuan yang didapat.

Pengetahuan Masyarakat tentang penggunaan daun sambiloto untuk pharyngitis di Desa Bakung, Jogonalan, Klaten, berdasarkan PendidikanTerdapat beberapa faktor yang mempengaruhi pengetahuan seseorang diantaranya adalah pendidikan, media massa atau informasi, sosial budaya dan ekonomi, lingkungan, pengalaman, usia dan pekerjaan (Budiman danRiyanto, 2013). Pengetahuan bukanlah sesuatu yang sudah ada dan tersedia dan sementara orang lain tinggal menerimanya. Pengetahuan adalah sebagai suatu pembentukan yang terus menerus oleh seseorang yang setiap saat mengalami reorganisasi karena adanya pemahaman-pemahaman baru (Notoatmodjo, 2003).

Pengetahuan Masyarakat Desa Bakung, Jogonalan, Klaten, berdasarkan tingkat pendidikan menunjukkan bahwa paling dominan adalah masyarakat yang berpendidikan akhir menangah atau dapat dikatakan berpendidikan SMA/Sederajat.
Dalam hal ini pendidikan menjadi salah satu faktor yang dapat mempengaruhi tingkat pengetahuan seseorang. Pendidikan adalah suatu usaha untuk mengembangkan kepribadian dan kemampuan di dalam dan di luar sekolah dan berlangsung seumur hidup. Pendidikan mempengaruhi proses belajar, makin tinggi pendidikan seseorang makin mudah orang tersebut untuk menerima informasi. Dengan pendidikan tinggi, maka seseorang akan cenderung untuk mendapatkan informasi baik dari orang lain maupun dari media massa lainnya (Budiman dan Riyanto, 2013).

Berdasarkan hasil pengumpulan data dapat diketahui bahwa tingkat pengetahuan Masyarakat Desa Bakung, Jogonalan, Klaten tentang penggunaan daun sambiloto untuk pharyngitis, menunjukkan bahwa dari masyarakat desa Bakung, Jogonalan, Klaten, paling banyak berpendidikan menengah atau berpendidikan SMA/sederajat dalam kategori berpengetahuan baik. Hal ini dikarenakan pada tingkat SMA atau sederajatmasyarakat termasuk pada taraf perkembangan pola pikir yang lebih dewasa sehingga pola pikir yang dihasilkan juga lebih baik.

Pengetahuan Masyarakat Desa Bakung, Jogonalan, Klaten tentang penggunaan daun sambiloto untuk pharyngitis. Hasil penelitian menunjukkan bahwa secara umum tingkat pengetahuan Masyarakat Desa Bakung, Jogonalan, Klaten tentang penggunaan daun sambiloto untuk pharyngitis, menunjukkan bahwa dari 30responden mayoritas mempunyai tingkat pengetahuan baik yaitu sebanyak 27 responden (90\%), sedangkan yang mempunyai tingkat pendidikan cukup sebanyak 3responden (10\%). Hal ini dapat 
disimpulkan bahwa tingkat pengetahuan masyarakat Desa Bakung, Jogonalan, Klaten, tentang penggunaan daun sambiloto untuk pharyngitis sudah tergolong dalam kategori baik. Hal ini dikarenakan mayoritas masyarakat aktif dan giat dalam mencari informasi khususnya tentang asam jawa untuk batuk. Selain itu masyarakat juga sering menapatkan informasi dari orang-orang sekitar yang berasal dari pengalaman pribadi karena mencoba asam jawa tersebut dan ternyata dapat batuk.

Menurut Notoatmodjo (2013), pengalaman pribadi dapat digunakan sebagai upaya memperoleh pengetahuan. Pengalaman yang dikembangkan dapat memberikan pengetahuan dan ketrampilan profesional serta dapat mengembangkan kemampuan mengambil keputusan yang merupakan manifestasi dari keterpaduan menalar secara ilmiah dan etik yang bertolak dari masalah nyata terkait dengan kondisi yang ada.

Oleh karena itu masyarakat perlu didasarkan akan pentingnya menjaga kesehatan khususnya organ pernafasan, agar tidak menderita batuk. Jika ingin, organ pernafasan sangat mudah terkena penyakit, karena udara yang kita hirup sudah banyak tercemar, hal ini yang sering kali menyebabkan pharyngitis.

\section{KESIMPULAN DAN SARAN}

Kesimpulan hasil penelitiani ini, Pengetahuan Masyarakat tentang penggunaan daun sambiloto untuk pharyngitis di Bakung, Jogonalan, Klaten tahun 2015 yang termasuk dalam tingkat pengetahuan baik sebanyak 27 orang (90\%), sedangkan yang cukup 3 orang (10\%). Karakteristik berdasarkan Umur di desa Bakung, Jogonalan, Klaten, prosentase paling banyak adalah berusia
$>20$ tahun sebanyak 29 responden (96,6\%). Karakteristik berdasarkan Pendidikan di Desa Bakung, Jogonalan, Klaten, prosentase paling banyak adalah SMA sebanyak 20 responden $(66,66 \%)$.

Saran untuk masyarakat berpengetahuan cukup, disarankan lebih banyak lagi mempelajari tentang khasiat penggunaan daun sambiloto untuk pharyngitis dan bagi peneliti lain, untuk meneliti lebih dalam tentang daun sambiloto baik khasiat, kandungan dan manfaat lainnya.

\section{DAFTAR RUJUKAN}

Budiman dan Riyanto A. 2013. Kapita Seleta Kuesioner Pengetahuan dan dan Sikap Dalam Penelitian Kesehatan, Jakarta: Salemba Medika

Brook, G.F., Butel, J.S., dan Morse, S.A., 2005, MikrobiologiKedokteran, Salemba Medika : Jakarta.

Hariana, H. Arief. 2011. Tumbuhan Obat dan Khasiatnya. Jilid 2. Jakarta. Penebar Swadaya.

Notoatmodjo, S. 2010. Ilmu Perilaku Kesehatan. Jakarta. Rineka Cipta.

Notoatmodjo, S. 2012. Metodologi Penelitian Kesehatan. Jakarta. Rineka Cipta.

Sugiyono. 2010. Metode Penelitian Kuantitatif, Kualitatif dan $R \& D$. Bandung. Alfabeta.

Zulkoni HA. 2011. Parasitologi. Yogyakarta. Nuha Medika. 